\title{
PERILAKU CARING PERAWAT BERDASARKAN FAKTOR INDIVIDU DAN ORGANISASI
}

\author{
Eva Supriatin* \\ Fakultas Ilmu Keperawatan, Universitas BSI Bandung, Bandung 40282, Indonesia \\ *E-mail: eva_asata@yahoo.com
}

\begin{abstract}
Abstrak
Perilaku caring perawat dapat meningkatkan perubahan positif dalam aspek fisik, psikologis, spiritual, dan sosial. Penelitian ini bertujuan untuk mengidentifikasi hubungan faktor individu dan organisasi dengan perilaku caring perawat. Desain penelitian ini adalah deskriptif korelasi dengan pendekatan cross sectional. Populasi penelitian ini adalah seluruh perawat pelaksana di empat ruang rawat inap suatu rumah sakit. Sampel penelitian berjumlah empat puluh tiga perawat secara total sampling. Hasil penelitian ini adalah ada hubungan usia $(\mathrm{p}=0,027 ; \alpha=0,05)$, masa kerja $(\mathrm{p}=0,001 ; \alpha=0,05)$, kepemimpinan $(\mathrm{p}=0,005 ; \alpha=0,05)$, struktur organisasi $(\mathrm{p}=0,001 ; \alpha=0,05)$, imbalan $(\mathrm{p}=0,037 ; \alpha=$ $0,05)$, dan desain kerja $(p=0,006 ; \alpha=0,05)$ dengan perilaku caring perawat. Saran dari penelitian ini adalah perlunya pembinaan yang berkaitan dengan kepemimpinan dan pengorganisasian pada perawat untuk meningkatkan perilaku caring perawat.
\end{abstract}

Kata kunci: perilaku caring perawat, faktor individu, faktor organisasi

\begin{abstract}
Nurse Caring Behavior based on Individual and Organization Factors. Nurse caring behavior will increase the positive impacts on physical, psychological, spiritual, and social. The purpose of the study was to idetify how the relationship of individual factors and organizational factors with the nurse caring behavior. The research design was a descriptive correlation using cross sectional. The study population was all nurses practtisioners in 4 (four) wards. Samples of this study were 43 nurses in total sampling. Results of this study was no related of age $(p=0,027 ; \alpha=0,05)$, year $(p=0,001 ; \alpha=0,05)$, leadership $(p=0,005 ; \alpha=0,05)$, organizational structure $(p=0,001 ; \alpha=0,05)$, reward $(p=$ $0,037 ; \alpha=0,05)$, and design work ( $p=0,006 ; \alpha=0,05)$ with the nurse caring behavior. Suggestions from these findings is related to the development of leadership and organization.
\end{abstract}

Keywords: individual factor, organisation factor, nurse caring behaviour

\section{Pendahuluan}

Caring sebagai inti keperawatan merupakan fokus/ sentral dari praktik keperawatan yang dilandaskan pada nilai-nilai kebaikan, perhatian, kasih terhadap diri sendiri dan orang lain, serta menghormati keyakinan spiritual klien. Caring dikatakan sebagai jantung dalam praktik keperawatan.

Leinenger (1997) dalam Watson (2004) mengatakan bahwa caring dapat terlihat pada perilaku perawat. Perilaku tersebut antara lain memberi rasa nyaman, memberikan perhatian, kasih sayang, peduli, memelihara kesehatan, memberi dorongan, empati, minat, cinta, percaya, melindungi, kehadiran, mendukung, memberi sentuhan, menunjukkan siap membantu, dan mengunjungi klien. Perilaku caring perawat akan membantu menolong klien dalam meningkatkan perubahan positif dalam aspek fisik, psikologis, spiritual, dan sosial.

Perilaku caring perawat pelaksana dalam asuhan keperawatan merupakan kinerja perawat yang dipengaruhi oleh tiga faktor, yaitu faktor individu, faktor organisasi, dan faktor psikologis (Gibson, 1997). Faktor individu meliputi kemampuan, keterampilan, latar belakang pribadi, dan demografis. Faktor psikologis banyak dipengaruhi oleh keluarga, 
tingkat sosial, pengalaman kerja sebelumnya, dan demografis. Faktor organisasi menurut Gibson (1997) terdiri atas variabel sumber daya, kepemimpinan, imbalan, struktur, dan desain pekerjaan.

Sebuah Rumah Sakit di Kota Bandung tipe C memiliki kapasitas tempat tidur sejumlah seratus lima pukuh tempat tidur. Laju penggunaan tempat tidur (BOR) 69,97\%. Instalasi rawat inap terdiri atas ruang rawat inap anak dengan rerata rasio perawat dengan klien $1: 12$, di ruang penyakit dalam $1: 14$, di ruang bedah $1: 5$, ruang kebidanan $1: 18$, dan ruang perinatal $1: 18$. Rasio tersebut menunjukkan adanya ketidakseimbangan rasio perawat dengan klien dan distribusi perawat yang tidak merata di setiap ruang rawat inap.

Evaluasi kinerja perawat ditinjau dari perilaku caring dalam asuhan keperawatan melalui hasil kotak saran klien di antaranya perawat hendaknya lebih gesit dalam memenuhi panggilan klien, lebih ramah, dan lebih sopan dalam berhadapan dengan klien. Hasil wawancara dengan beberapa perawat di ruang rawat inap didapatkan bahwa perawat bekerja sebatas rutinitas, jenjang karier yang tidak jelas, sistem insentif yang kurang memadai, dan kurang mendapatkan perhatian dari pimpinan. Peneliti belum menemukan adanya hubungan faktor individu (usia dan pengalaman) dan faktor organisasi (kepemimpinan, imbalan, struktur organisasi, dan jenjang karier) dengan perilaku caring perawat.

\section{Metode}

Penelitian ini merupakan penelitian kuantitatif dengan pendekatan cross sectional. Populasi penelitian ini adalah empat puluh tiga perawat pelaksana pada instalasi rawat inap rumah sakit (RS) di Kota Bandung pada 22-30 Juni 2009 (total sampling). Instrumen penelitian berupa kuesioner yang disusun berdasarkan skala Likert. Instrumen dikembangkan berdasarkan konsep faktor individu, faktor organisasi, dan perilaku caring. Hasil uji coba kuesioner menunjukkan kuesioner valid $(0,3705-0,9266)$ dan reliabel $(0,9615-0,9709)$ untuk seluruh kuesioner. Data dianalisis secara univariat dan bivariat (uji t-independent dan Kai kuadrat).

\section{Hasil}

Perilaku Caring Perawat. Penelitian ini menggunakan enam indikator perilaku caring perawat (Watson, 2004) adalah meliputi accessible, explain-fasilatates, comfort, anticipates, trusting relationship, dan monitors-follows. Alat ukur yang digunakan untuk menilai perilaku caring perawat menggunakan Care $Q$ (The Nurse Behaviour Caring Study) Larson.

Hasil penelitian pada Tabel 1 menunjukkan sebagian besar $(58,1 \%)$ perilaku caring perawat pelaksana masih kurang.

Faktor Individu dengan Caring Perawat. Subvariabel kemampuan dan keterampilan merupakan faktor utama yang memengaruhi perilaku dan individu. Subvariabel demografis, menurut (Gibson, 1997), mempunyai efek tidak langsung pada perilaku dan kinerja individu, namun karakteristik demografik merupakan hal yang penting diketahui oleh pimpinan atau seorang dalam memotivasi dan meningkatkan kinerjanya. Karakteristik demografi meliputi usia, jenis kelamin, latar belakang pendidikan, masa kerja, dan status perkawinan.

Rerata usia perawat pelaksana adalah 28,7 tahun dengan usia termuda 22 tahun dan tertua 43 tahun. Rerata masa kerja perawat adalah 6,05 tahun dengan lama kerja tersingkat 2 tahun dan terlama 16 tahun, sebagian besar perawat berjenis kelamin perempuan $(74,4 \%)$, berpendidikan D-3 (90,7\%), dan telah menikah $(79,1 \%)$. Hasil dapat dilihat pada Tabel 2 dan Tabel 3.

Tabel 1. Perilaku Caring Perawat

\begin{tabular}{lcc}
\hline \multicolumn{1}{c}{ Perilaku Caring } & f & \% \\
\hline a. Kurang Baik & 25 & 58,1 \\
b. Baik & 18 & 41,9 \\
\hline
\end{tabular}

Tabel 2. Karakteristik Responden berdasarkan Umur dan Masa Kerja

\begin{tabular}{ccccc}
\hline Variabel & Mean & SD & $\begin{array}{c}\text { Min- } \\
\text { Mak }\end{array}$ & 95\% CI \\
\hline a.Umur & 28,70 & 3,66 & $22-43$ & $27,57-29,82$ \\
b.Masa & 6,05 & 3,10 & $2-16$ & $5,09-7,00$ \\
Kerja & & & & \\
\hline
\end{tabular}


Hasil penelitian menunjukkan terdapat hubungan antara usia perawat yang perilaku caring perawat $(p=0,027 ; \alpha=0,05)$. Masa kerja perawat juga berhubungan dengan perilaku caring perawat $(p=0,001 ; \alpha=0,05)$. Tampak pada Tabel 4 .

Pendidikan dan jenis kelamin tidak berhubungan dengan perilaku caring perawat pelaksana $(\mathrm{p}=$ 0,398; $\alpha=0,05)$ tergambar pada Tabel 5 .

Faktor Organisasi dengan Perilaku Caring Perawat. Variabel organisasi menurut Gibson (1997) berefek tidak langsung terhadap perilaku dan kinerja individu. Variabel organisasi digolongkan dalam subvariabel sumber daya, kepemimpinan, imbalan, struktur, dan desain pekerjaan.

Hasil penelitian didapatkan persepsi perawat pelaksana kurang tentang kepemimpinan $(58,1 \%)$, struktur organisasi $(51,2 \%)$, dan desain kerja $(62,8 \%)$. Akan tetapi, yang dipersepsikan baik oleh perawat pelaksana adalah imbalan $(53,5 \%)$. Hasil tampak pada Tabel 6.

Tabel 3. Karakteristik Responden berdasarkan Pendidikan dan Jenis Kelamin

\begin{tabular}{lcc}
\hline \multicolumn{1}{c}{ Variabel } & F & \% \\
\hline $\begin{array}{l}\text { Pendidikan } \\
\text { a.Surat Perintah Kerja }\end{array}$ & 1 & 2,3 \\
(SPK) & 39 & 90,7 \\
bD-3 Keperawatan & 3 & 7 \\
c.S-1 Keperawatan & & \\
Jenis Kelamin: & 11 & 25,6 \\
a.Laki-Laki & 32 & 74,4 \\
b.Perempuan & & \\
\hline
\end{tabular}

Tabel 4. Hubungan Umur dan Masa Kerja Perawat dengan Perilaku Caring Perawat

\begin{tabular}{cccccc}
\hline Variabel & $\begin{array}{c}\text { Variabel } \\
\text { dependen }\end{array}$ & Mean & SD & p & N \\
\hline a. Umur & $\begin{array}{c}\text { Perilaku } \\
\text { caring }\end{array}$ & & & & \\
& Kurang & 27,5 & 2,06 & 0,137 & 66 \\
& Baik & 30,3 & 4,71 & & 75 \\
b. Masa & Perilaku & & & & \\
Kerja & caring & & & & \\
& Kurang & 4,6 & 1,5 & 0,066 & 66 \\
& Baik & 8,0 & 3,7 & & 75 \\
\hline
\end{tabular}

Tabel 5. Hubungan Pendidikan dan Jenis Kelamin dengan Perilaku Caring Perawat

\begin{tabular}{|c|c|c|c|c|c|c|}
\hline \multirow{3}{*}{ Variabel } & \multicolumn{4}{|c|}{ Perilaku Caring } & \multirow{3}{*}{$\mathbf{N}$} & \multirow{3}{*}{$\mathbf{p}$} \\
\hline & \multicolumn{2}{|c|}{ Kurang } & \multicolumn{2}{|c|}{ Baik } & & \\
\hline & $\mathbf{n}$ & $\%$ & $\mathbf{n}$ & $\%$ & & \\
\hline \multicolumn{7}{|l|}{ Pendidikan } \\
\hline a.SPK/D-3 & 23 & 59,0 & 17 & 41,0 & 40 & 0,39 \\
\hline b.S-1 & & & & & & 8 \\
\hline Keperawtan & 2 & 66,7 & 1 & 33,3 & 3 & \\
\hline \multicolumn{7}{|l|}{ Jenis } \\
\hline \multicolumn{7}{|l|}{ Kelamin } \\
\hline a.Laki-Laki & 6 & 54,5 & 5 & 45,5 & 11 & 0,52 \\
\hline b.Perempuan & 19 & 59,5 & 13 & 40,6 & 32 & 5 \\
\hline
\end{tabular}

Tabel 6. Faktor Organisasi

\begin{tabular}{lcc}
\hline Variabel & f & $(\mathbf{\% )}$ \\
\hline $\begin{array}{l}\text { Faktor Organisasi } \\
\text { Subvariabel } \\
\text { Kepemimpinan }\end{array}$ & & \\
$\begin{array}{l}\text { a. Kurang } \\
\text { b. Baik }\end{array}$ & & \\
& 25 & 58,1 \\
Struktur organisasi & 18 & 41,9 \\
a. Kurang & & \\
b. Baik & 22 & 51,2 \\
& 21 & 48,8 \\
Imbalan & & \\
$\begin{array}{l}\text { a. Kurang } \\
\text { b. Baik }\end{array}$ & & \\
& 20 & 46,5 \\
Desain kerja & 23 & 53,5 \\
a. Kurang & & \\
b. Baik & & \\
\hline
\end{tabular}

Hasil penelitian pada faktor organisasi menunjukkan terdapat hubungan bermakna antara persepsi perawat terhadap kepemimpinan kepala ruangan, struktur organisasi, imbalan, dan desain kerja dengan perilaku caring perawat pelaksana $(\mathrm{p} \leq$ $0,05(\alpha=0,05)$. Hasil tersebut dapat dilihat pada Tabel 7.

\section{Pembahasan}

Perilaku Caring Perawat. Hasil penelitian menunjukkan sebagian besar perilaku caring perawat pelaksana masih kurang. Hal ini dapat terjadi karena kebanyakan perawat terlibat secara aktif dan memusatkan diri pada fenomena medik, 
Tabel 7. Hubungan Kepemimpinan, Struktur Organisasi, Imbalan, dan Desain kerja dengan Perilaku Caring Perawat

\begin{tabular}{|c|c|c|c|c|c|c|}
\hline \multirow{3}{*}{ Variabel } & \multicolumn{4}{|c|}{ Perilaku Caring } & \multirow{3}{*}{$\begin{array}{c}\text { Total } \\
\mathrm{N} \\
\end{array}$} & \multirow{3}{*}{$\mathrm{p}$} \\
\hline & \multicolumn{2}{|c|}{ Kurang } & \multicolumn{2}{|c|}{ Baik } & & \\
\hline & $\mathrm{n}$ & $\%$ & $\mathrm{n}$ & $\%$ & & \\
\hline $\begin{array}{l}\text { Kepemimpinan } \\
\text { a. Kurang } \\
\text { b. Baik }\end{array}$ & $\begin{array}{c}19 \\
6\end{array}$ & $76,033,3$ & $\begin{array}{c}6 \\
12\end{array}$ & $\begin{array}{l}41,0 \\
33,3\end{array}$ & $\begin{array}{c}40 \\
3\end{array}$ & 0,005 \\
\hline Struktur organisasi & & & & & & \\
\hline a. Kurang & 18 & 81,8 & 4 & 18,2 & 22 & 0,001 \\
\hline & 7 & 33,3 & 14 & 66,7 & 21 & \\
\hline a. Kurang & 15 & 75 & 5 & 25 & 20 & 0,037 \\
\hline b. Baik & 10 & 43,5 & 13 & 56,5 & 23 & \\
\hline $\begin{array}{l}\text { Desain pekerjaan } \\
\text { a. Kurang } \\
\text { b. Baik }\end{array}$ & $\begin{array}{c}20 \\
5 \\
\end{array}$ & $\begin{array}{l}74,1 \\
31,3 \\
\end{array}$ & $\begin{array}{c}7 \\
11\end{array}$ & $\begin{array}{r}25,9 \\
68,8 \\
\end{array}$ & $\begin{array}{l}27 \\
16 \\
\end{array}$ & 0,006 \\
\hline
\end{tabular}

seperti cara diagnostik dan cara pengobatan. Akibatnya, perawat kekurangan waktu dalam memberikan perhatian pada tugas care klien.

Beberapa bukti empirik yang mendukung kurangnya perilaku caring perawat, yaitu hasil penelitian Greenhalgh, Vanhanen, dan Kyngas (1998). Penelitian yang bertujuan menelaah perilaku perawat yang bekerja di ruang perawatan umum menunjukkan bahwa perawat lebih menekankan perilaku caring fisik daripada afektif. Pemenuhan kebutuhan biologis menjadi fokus utama perawat sehingga kebutuhan lainnya seperti kebutuhan psikologis, sosial, dan spiritual klien kurang mendapat perhatian.

Perilaku caring perawat yang kurang menurut Greenhalgh, Vanhanen, dan Kyngas (1998) disebabkan jumlah perawat yang sangat terbatas dengan jumlah klien yang banyak (rasio perawat: klien adalah 1:12-18). Perawat juga belum memahami makna caring, baik arti caring, spirit caring, maupun tindakan atau wujud nyata dari perilaku caring.

Faktor Individu dengan Caring Perawat. Umur perawat yang berada pada masa produktif di RS ini berhubungan dengan perilaku caring-nya. Pada umur ini memungkinkan perawat dalam masa kedewasaan dan kematangan. Dessler (1997) menekankan bahwa umur produktif adalah usia 25-30 tahun di mana pada tahap ini merupakan penentu seseorang untuk memilih bidang pekerjaan yang sesuai bagi karir individu tersebut. Umur 30-40 tahun merupakan tahap pemantapan pilihan karier untuk mencapai tujuan. Namun, puncak karier terjadi pada umur 40 tahun. Menurut Siagian (1999), semakin lanjut umur seseorang semakin meningkat pula kedewasaan teknisnya, demikian pula psikologis, menunjukkan kematangan jiwa. Perawat di RS ini menjadi modal dasar dalam mengembangkan sumber daya manusia (SDM) dilihat secara umur.

Masa kerja perawat di RS tersebut berhubungan dan bermakna dengan perilaku caring-nya. Robbins (1998) menguraikan bahwa semakin lama seseorang bekerja semakin terampil dan akan lebih berpengalaman dalam melaksanakan pekerjaannya. Masa kerja perawat RS tersebut berpengaruh terhadap pengalaman kerja. Hal ini dapat dilihat dari adanya perawat senior berdasarkan lama kerja yang dijadikan role model dan dijadikan acuan bagi perawat muda dalam berperilaku caring.

Jenis kelamin perawat tidak berhubungan dengan perilaku caring-nya. Penelitian ini didukung Aminuddin (2004) yang menyatakan bahwa tidak ada perbedaan kinerja perawat laki-laki dengan perempuan. 
Hasil penelitian ini tidak didukung oleh hasil penelitian Greenhalgh, Vanhanen dan Kyngas (1998) yang mendapatkan hubungan antara jenis kelamin perawat dengan perilaku caring. Adanya perbedaan ini dapat disebabkan oleh adanya perbedaan budaya, kebiasaan, nilai, dan faktor lainnya. Saat ini perbedaan gender sudah tidak berlaku di masyarakat. Perawat perempuan memiliki tugas dan kewajiban yang sama dengan perawat laki-laki.

Tingkat pendidikan tidak berhubungan dengan perilaku caring perawat pelaksana di RS ini. Hasil ini tidak sependapat dengan Siagian (1999) yang mengatakan bahwa tingkat pendidikan memengaruhi kinerja perawat yang bersangkutan. Tenaga keperawatan yang berpendidikan tinggi kinerjanya akan lebih baik karena telah memiliki pengetahuan dan wawasan yang lebih luas.

Pendapat peneliti berdasarkan identifikasi dan referensi, caring merupakan ilmu tentang manusia, bukan hanya sebagai perilaku, melainkan juga suatu cara sehingga sesuatu menjadi berarti dan memberi motivasi untuk berbuat kepedulian terhadap klien. RS ini baru selesai menyekolahkan perawat berpendidikan SPK sehingga belum ada tampak perbedaan perawat berpendidikan SPK dengan D-3 Keperawatan.

Status perkawinan tidak berhubungan dengan perilaku caring perawat pelaksana. Hasil ini sesuai dengan penelitian Rusmiati (2008) yang menyatakan tidak ada hubungan status pernikahan dengan kinerja.

\section{Perilaku Caring Perawat Berdasarkan Faktor Organisasi (Kepemimpinan, Struktur Orga- nisasi, Imbalan, dan Desain Kerja). Persepsi perawat pelaksana terhadap kepemimpinan kepala ruangan berhubungan dengan perilaku caring-nya. Hasil ini didukung Aminudin (2004) yang men- dapatkan adanya hubungan antara kepemimpinan dengan kinerja.}

Pada organisasi, kepemimpinan terletak pada usaha memengaruhi aktivitas orang lain individu atau kelompok melalui komunikasi untuk mencapai tujuan organisasi dan prestasi (Swansburg dan
Swansburg, 1999). Seorang kepala ruangan yang merupakan firts line manager berfungsi sebagai seorang pemimpin yang akan memengaruhi stafnya dalam berperilaku dan bekerja. Setiap kepala ruangan harus memiliki pengetahuan, sikap, dan berperilaku sebagai seorang pemimpin dengan mengetahui prinsip dari kepemimpinan.

Persepsi perawat pelaksana terhadap struktur organisasi ruangan berhubungan dengan perilaku caring perawat pelaksana. Kondisi ini terjadi karena Robbins (1998) menekankan bahwa struktur organisasi menunjukkan cara suatu kelompok dibentuk, garis komunikasi, dan hubungan otoritas, serta pembuatan keputusan. Struktur organisasi ini menunjukkan garis kewenangan dan rentang kendali dari suatu organisasi yang akan menentukan kegiatan dan hubungan serta ruang lingkup tanggung jawab dan peran setiap individu.

Belum adanya desain kerja, menimbulkan setiap orang tidak mengetahui tupoksinya sehingga tugas dan kewenangan masing-masing individu tidak jelas. Kepala ruangan memberikan tugas belum berdasarkan kemampuan dan kesanggupan perawat pelaksana. Hal ini disebabkan oleh terbatasnya jumlah perawat pelaksana yang ada di setiap rawat inap. Standar Operasional Prosedur (SOP) dan Standar Akuntansi Keuangan (SAK) pun belum dijadikan sebagai acuan dalam melakukan pelayanan keperawatan. Hal ini terlihat dalam melakukan tindakan keperawatan banyak yang tidak sesuai dengan SOP dan SAK rumah sakit.

Persepsi perawat pelaksana terhadap imbalan berhubungan dengan perilaku caring perawat pelaksana. Desler dalam Samsudin (2005), Hasibuan (2003), dan Wibowo (2007) mengutarakan imbalan/ kompensasi mengandung makna pembayaran/ imbalan baik langsung maupun tidak langsung yang diterima karyawan sebagai hasil dari kinerja.

Hasibuan (2003) dan Wibowo (2007) menjelaskan bahwa status kepegawaian sangat berkaitan dengan besarnya imbalan pegawai. Imbalan tersebut menjadi salah satu motivasi pegawai untuk bekerja dan menunjukkan kinerja. Perawat RS dengan status pegawai negeri merupakan kekuatan dan motivasi perawat untuk meningkatkan kinerja 
dari aspek finansial. Imbalan dalam nonfinansial pun dibutuhkan untuk memotivasi dan meningkatkan kinerja. Kurangnya penghargaan kepada perawat berprestasi dan perawat yang caring dapat menurunkan motivasi perawat untuk caring pada klien.

Pemberian kompensasi yang baik akan mendorong karyawan bekerja secara produktif dan organisasi yang sukses dapat terlihat dari besarnya kompensasi yang diberikan oleh organisasi. Jika seseorang menggunakan pengetahuan, keterampilan, tenaga, dan sebagian waktunya untuk berkarya pada suatu organisasi, ia akan mengharapkan kompensasi/ imbalan tertentu.

Persepsi perawat pelaksana terhadap desain pekerjaan berhubungan dengan perilaku caring perawat pelaksana. Hal ini disebabkan oleh kurangnya pemberian otonomi kepada perawat, kurangnya kewenangan, kurangnya bimbingan kepada perawat, dan faktor senioritas menjadi penghambat bagi perawat dalam berperilaku caring.

Penelitian ini dapat berdampak positif dan menjadi masukan bagi pelayanan keperawatan khususnya dalam meningkatkan perilaku caring perawat. Kompetensi pemimpin, seperti kepala ruangan juga memengaruhi perilaku caring perawat pelaksana. Pihak RS perlu lebih memperhatikan dan memprioritaskan kompetensi kepala ruangan, sebagai manajer first line yang harus dapat berperan sebagai pemimpin. Kepala ruangan yang mampu berperan sebagai role model dapat memotivasi perawat pelaksana berperilaku caring.

\section{Kesimpulan}

Perawat pelaksana di instalasi rawat inap RS tersebut sebagian besar kurang berperilaku caring . Faktor individu (umur dan masa kerja) serta faktor organisasi (kepemimpinan kepala ruangan, struktur organisasi, imbalan, dan desain kerja) berhubungan perilaku caring perawat pelaksana.

Peneliti menyarankan perlu dukungan kebijakan atas perilaku caring perawat oleh pihak RS ke dalam pelayanan asuhan keperawatan dalam upaya meningkatkan kinerja perawat dan mutu pelayanan keperawatan. caring perawat perlu dimasukkan ke dalam penilaian kinerja perawat dalam rangka meningkatkan motivasi perawat dalam bekerja (MS, HH, TN).

\section{Referensi}

Aminudin, T.Y. (2004). Hubungan iklim kerja dengan kinerja perawat pelaksana di Ruang Rawat Inap RSUD Dr. M. Yunus Bengkulu. (Tesis, tidak dipublikasikan). Program Studi Magister Fakultas Ilmu Keperawatan Universitas Indonesia, Depok, Jawa Barat.

Dessler, G. (1997). Manajemen sumber daya manusia. Terjemahan (1st Ed.). Jakarta: PT Prentallindo.

Gibson, J.L. (1997). Organisasi: Perilaku, struktur, proses (Edisi kedelapan). (Nunuk. A, Penerjemah). Jakarta: Binarupa Aksara.

Greenhalgh, J., Kyngas, H., \& Vanhanen, L. (1998). Nurse caring behavior. Journal of Advanced Nursing, 27 (5), 927-932.

Hasibuan, M.S.P. (2003). Manajemen sumber daya manusia (edisi revisi). Jakarta: PT Bumi Aksara.

Robbins, S.P. (1998). Perilaku Organisasi, konsep, kontroversi, dan aplikasi (Edisi kedelapan). Jakarta: PT. Prenhallindo.

Rusmiati. (2008). Hubungan lingkungan organisasi dan karakteristik perawat dengan kinerja perawat pelaksana di ruangan rawat inap Rumah Sakit Umum Pusat Persahabatan Jakarta (Tesis, tidak dipublikasikan). Program Magister Ilmu Keperawatan Fakultas Ilmu Keperawatan Universitas Indonesia, Depok, Jawa Barat.

Samsudin, S. (2005). Manajemen sumber daya manusia. Bandung: CV Pustaka Setia.

Siagian, S.P. (1999). Manajemen sumber daya manusia. Jakarta: Bumi Aksara.

Siagian, S.P. (2000). Teori dan Praktek Kepemimpinan (Cetakan kelima). Jakarta: PT Rineke Cipta. 
Swansburg, R.C., \& Swansburg, R.J. (1999). Introductory management and leadership for nurse (2nd Ed.). Boston: Jones and Bartlet Publishers.

Watson, J. (2004). Assessing and measuring caring in nursing and health science (2nd Ed.). New York: Springer Publication Company.
Wibowo. (2007). Manajemen kinerja. Jakarta: PT Raja Grufindo Persada. 